\title{
Enzymatic response of Macrobrachium jelskii (Miers, 1877) exposed to water from urban and rural rivers in Bahia, Brazil
}

Resposta enzimática de Macrobrachium jelskii (Miers, 1877) exposto à água de rios urbanos e rurais na Bahia, Brasil

Respuesta enzimática de Macrobrachium jelskii (Miers, 1877) expuesto al agua de ríos urbanos y rurales en Bahía, Brasil

Received: 04/30/2021 | Reviewed: 05/18/2021 | Accept: 05/20/2021 | Published: 06/06/2021

\author{
Thais Arrais Mota \\ ORCID: https://orcid.org/0000-0002-3618-1777 \\ Universidade Estadual de Santa Cruz, Brazil \\ E-mail: thai_motta@hotmail.com \\ Elissandra Ulbricht Winkaler \\ ORCID: https://orcid.org/0000-0003-3297-4283 \\ Universidade Federal do Recôncavo da Bahia, Brazil \\ E-mail: elis@ufrb.edu.br \\ Guilherme de Oliveira \\ ORCID: https://orcid.org/0000-0003-3165-5088 \\ Universidade Federal do Recôncavo da Bahia, Brazil \\ E-mail: guilhermeoliveira@ufrb.edu.br \\ Sergio Schwarz da Rocha \\ ORCID: https://orcid.org/0000-0002-2594-2745 \\ Universidade Federal do Recôncavo da Bahia, Brazil \\ E-mail: ssrocha@ufrb.edu.br
}

\begin{abstract}
Several biomarker enzymes such as catalase (CAT) and glutathione S-transferase (GST) can be used to measure oxidative stress in animals caused by exposure to xenobiotics. The objective of the present study was to characterize different points of the Capivari (CP1 and CP2), Paraguaçu (PG1 and PG2) and Subaé (SB1 and SB2) Rivers, state of Bahia, in relation to the presence of xenobiotics, using CAT and GST as bioindicators in $M$. jelskii. The water-sampling sites were considered urban or rural and in all of them signs of environmental degradation were observed. Therefore, acute exposure tests (96h) were performed with water samples collected during the dry and rainy seasons. Results showed that the activity of CAT and GST in prawns exposed to water from CP1 and CP2 were very similar, while those exposed to water from PG1, PG2, SB1 and SB2 formed distinct groups of data. Significant increase in the activity of at least one of the analyzed enzymes in each sampling site was observed, when compared to animals in the control group. This demonstrated a possible oxidative stress in M. jelskii caused by the presence of xenobiotics in the water (e.g., domestic sewage, pesticides, oil, and heavy metals). Enzymatic activities were higher in animals from experiments carried out in the rainy season, except for the CAT activity of animals exposed to water from Subaé River. This study demonstrated the potential of $M$. jelskii as bioindicator and contributed to the knowledge of aspects of the antioxidant defense system of this species.
\end{abstract}

Keywords: Catalase; Glutathione S-transferase; Prawn; Ecotoxicology; Bioindicator.

\section{Resumo}

Várias enzimas biomarcadoras, como a catalase (CAT) e a glutationa S-transferase (GST), podem ser usadas para medir o estresse oxidativo em animais causado pela exposição a xenobióticos. O objetivo deste estudo foi caracterizar diferentes pontos dos rios Capivari (CP1 e CP2), Paraguaçu (PG1 e PG2) e Subaé (SB1 e SB2), localizados no estado da Bahia, em relação à presença de xenobióticos, utilizando CAT e GST como bioindicadores em $M$. jelskii. Os pontos de amostragem de água foram considerados urbanos ou rurais e em todos eles foram observados sinais de degradação ambiental. Para tanto, foram realizados testes de exposição aguda (96h), com amostras de água coletadas durante as estações seca e chuvosa. Os resultados mostraram que a atividade de CAT e GST em camarões expostos à água de CP1 e CP2 foram muito semelhantes, enquanto aqueles expostos à água de PG1, PG2, SB1 e SB2 formaram grupos de dados distintos. Observou-se aumento significativo da atividade de pelo menos uma das enzimas analisadas nos locais de amostragem, quando comparada aos animais do grupo controle. Isso demonstrou um possível estresse oxidativo em M. jelskii, causado 
pela presença de xenobióticos na água (e.g., esgoto doméstico, pesticidas, óleo e metais pesados). As atividades enzimáticas foram maiores nos animais dos experimentos realizados no período chuvoso, exceto para a atividade da CAT dos animais expostos à água do Rio Subaé. Este estudo demonstrou o potencial de $M$. jelskii como bioindicador e contribuiu para o conhecimento de aspectos do sistema de defesa antioxidante dessa espécie.

Palavras chave: Catalase; Glutadiona S-transferase; Camarão; Ecotoxicologia; Bioindicador.

\section{Resumen}

Varias enzimas biomarcadores, como la catalase (CAT) y la glutatión S-transferase (GST), pueden usarse para medir el estrés oxidativo en animales causado por la exposición a xenobióticos. El objetivo de este estudio fue caracterizar diferentes puntos de los ríos Capivari (CP1 y CP2), Paraguaçu (PG1 y PG2) y Subaé (SB1 y SB2), ubicados en el estado de Bahía, en relación a la presencia de xenobióticos, utilizando CAT y GST como bioindicadores en $M$. jelskii. Los puntos de muestreo de agua se consideraron urbanos o rurales y en todos se observaron signos de degradación ambiental. Para ello, se realizaron pruebas de exposición aguda (96h), con muestras de agua recolectadas durante la época seca y lluviosa. Los resultados mostraron que la actividad de CAT y GST en camarones expuestos al agua de CP1 y CP2 fueron muy similares, mientras que los expuestos al agua de PG1, PG2, SB1 y SB2 formaron distintos grupos de datos. Hubo un aumento significativo en la actividad de al menos una de las enzimas analizadas en los sitios de muestreo, en comparación con los animales del grupo de control. Esto demostró un posible estrés oxidativo en $M$. jelskii, causado por la presencia de xenobióticos en el agua (e.g., aguas residuales domésticas, pesticidas, aceite y metales pesados). Las actividades enzimáticas fueron mayores en los animales de los experimentos realizados en época de lluvias, a excepción de la actividad CAT de los animales expuestos al agua del río Subaé. Este estudio demostró el potencial de $M$. jelskii como bioindicador y contribuyó al conocimiento de aspectos del sistema de defensa antioxidante de esta especie.

Palabras clave: Catalase; Glutatión S-transferase; Camarón; Ecotoxicología; Bioindicador.

\section{Introduction}

In the past few decades, aquatic ecosystems have been significantly affected by various environmental factors and impacts caused by the expansion of human activity and so water pollution in the urban aquatic environment became a major concern (Chen et al., 2014; Mendoza et al., 2017; Restello et al, 2020). As a typical urban aquatic environment, the urban water channel has been regarded as the fore-end part of the natural water bodies and the primary pollutant carrier that receives wastewater and polluted surface runoff. The variation of anthropogenic associated pollutants makes it difficult for cities to maintain a good status of urban surface waters (Wang et al., 2020).

Often, quantifying the concentrations of xenobiotics present in water is costly and does not provide the real impact on the organisms that live in the environment (Schirmer et al., 2011). Thus, ecotoxicological tests with biomarkers have been used to assess the effects of toxic chemicals on different ecosystems (Adams \& Greeley, 2000; Rosner et al., 2021). In addition, their responses can be used to estimate exposure to chemicals or resulting effects on aquatic organisms (Ramsdorf et al., 2012; Araujo et al., 2017).

Exposure of animals to xenobiotics can lead to the production of Reactive Oxygen Species (ROS), which in turn can induce changes in biochemical and cellular activities in animals, leading to the production or inhibition of substances that can be used as biomarkers (Van der Oost et al., 2003). Oxidative stress and production of ROS have, for example, been positively correlated with accumulation of heavy metals in aquatic organisms (Orebiyi et al., 2010; Tumminello \& Fuller-Espie, 2013; Dedeke et al., 2016), exposed to hydrocarbons (Tim-Tim et al., 2009; Lushchak, 2011; Al-Fanharawi et al., 2018; Turja et al., 2020), pesticides (Lavarías et al., 2013; Lavarías \& Garcia, 2015; Gaume et al. 2015; Lafontaine et al., 2017; Vieira et al., 2014), pharmaceutical products and surfactants (Canesi et al., 2010; Bolong et al., 2009; Saénz et al., 2010).

Several biomarker enzymes can be used to measure oxidative stress in animals. In this context, Catalase (CAT) is an antioxidant enzyme that acts against ROS by converting $\mathrm{H}_{2} \mathrm{O}_{2}$ into $\mathrm{H}_{2} \mathrm{O}$ and $\mathrm{O}_{2}$, and is mainly involved in the reduction of $\mathrm{H}_{2} \mathrm{O}_{2}$ produced from the metabolism of long-chain fatty acids into peroxisomes (Afiyanti \& Chen, 2014; Liu et al., 2020). Similarly, enzyme glutathione S-transferase (GST) is a biochemical biomarker involved in cellular detoxification of electrophilic compounds and shows initial signs of stress caused by pollutants (Lushchak, 2011). GST combines with ROS and 
interrupts the damage caused by these reactive species to the animal metabolism (Van Der Oost et al., 2003; Lushchak, 2011). Thus, biochemical markers are frequently used in toxicological studies to improve the understanding of the sublethal effects of pollutants on the health of organisms (Weis, 2014). Fish and prawn are considered potential bioindicators of the aquatic ecosystem for monitoring and evaluating water contamination (Hasan et al., 2020).

Macrobrachium jelskii (Miers, 1877) is a palemonid prawn with wide geographical distribution found in lotic or lentic environments with generalist feeding habits (Melo, 2003). Similarly, to other macroinvertebrates, the benthic habit of some decapod crustaceans enhances the likelihood of coming into contact with pollutants (Davanso et al., 2013; Key et al., 2006; Costa et al., 2008; Lavarías \& Garcia, 2015), making them effective bioindicators.

Although several biological and ecological aspects of M. jelskii have been studied, data regarding toxicology is scarce, especially with respect to research exploring the potential biomarkers in this species. Thus, the objective of the present study was to identify the most contaminated sites in three urban rivers in the state of Bahia, using the response of two biochemical biomarkers of this prawn species. We focused on answering the following question: can the activity of CAT and GST enzymes of Macrobrachium jelskii be used as biomarkers of aquatic contamination? Therefore, we investigated (i) the activity of the CAT and GST enzymes of M. jelskii after $96 \mathrm{~h}$ of exposure to water from river sites; (ii) the relationship between the response of CAT and GST activity and the probable source of contamination in the rivers water; (iii) the potential of M. jelskii as bioindicator in ecotoxicological tests to determine water quality, and; (iv) the influence of seasonality on the activity of CAT and GST enzymes.

\section{Methodology}

\subsection{Bioindicators}

M. jelskii specimens were collected from an artificial pond at "Engenho São João" Farm $\left(10^{\circ} 42^{\prime} 14.9\right.$ "S; $039^{\circ} 02^{\prime} 58.9^{\prime \prime} \mathrm{W}$ ), in the countryside of the municipality of Cruz das Almas, state of Bahia. Individuals were sampled by sweeping a sieve (diameter of $50 \mathrm{~cm}$, mesh of $0.5 \mathrm{~mm}$ ) through the partially submerged vegetation along riverbanks. At the collecting site, specimens were stored in plastic containers with water from the pond and then transported to the laboratory.

In the laboratory, animals were submitted to depuration process for 10 days in order to observe health conditions, recover from stress caused by transport and adapt to new water conditions (Apha et al., 1998). For this, prawns were kept in glass containers $(50 \mathrm{~L})$ filled with water from the local supply system (previously dechlorinated) with constant aeration from air blowers. Water temperature was maintained at $24.0 \pm 1.0^{\circ} \mathrm{C}$, in room with air conditioning system and controlled photoperiod (12h / light: 12h / dark). During the depuration process, animals received fish feed ad libitum, feces were removed by siphoning and the water volume was replaced. Finally, feeding was suspended 24 hours before the beginning of the experiment.

\subsection{Study area and collection of water samples}

Water samples were collected from three rivers (Paraguaçu, Subaé and Capivari) in the "Recôncavo da Bahia" region, state of Bahia, Brazil (Figure 1) from February to June 2017. Water collection sites were chosen based on the characteristics of each area according to anthropic influence and history of pollution. 
Figure 1. Map of South America, highlighting Brazil and the state of Bahia. Water sampling sites at: A- Capivari River (red circles); B - Paraguaçu River (green circles); and C - Subaé River (yellow circle). The black area in maps A and B indicate the Pedra do Cavalo Reservoir.

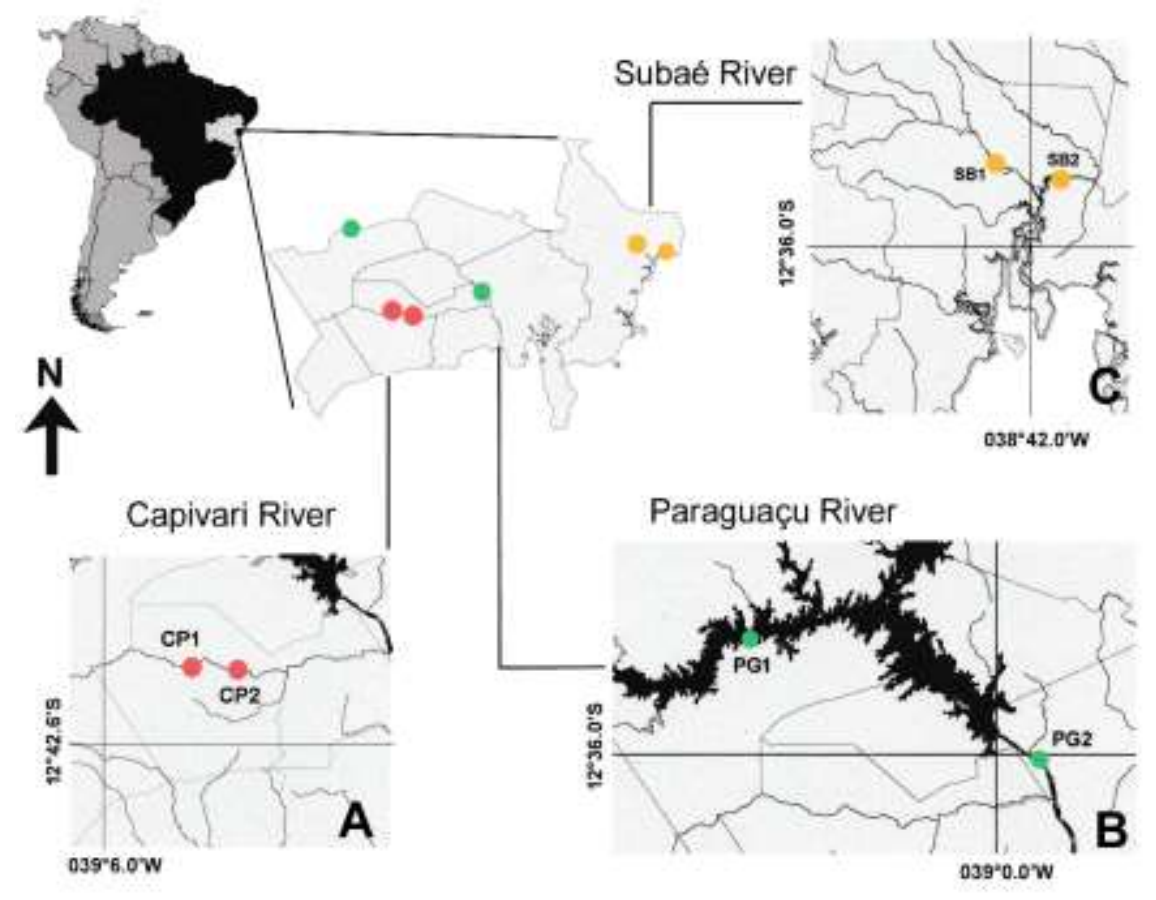

Source: Authors.

The spring of the Capivari River is in the municipality of Castro Alves and its mouth is in the municipality of São Félix, where it joins the Paraguaçu River downstream the Pedra do Cavalo Dam. The river runs through agricultural and pasture areas, and there are sources of discharge of domestic sewage along its course. Collection points were: CP1 - district of São José do Itaporã (12 $\left.38^{\prime} 43.00^{\prime \prime S} 039^{\circ} 7^{\prime} 15.40 " \mathrm{~W}\right)$, located in the municipality of Muritiba, with intense rural activity; and CP2 - located within the city limits of Cruz das Almas (12 $\left.38^{\prime} 50.90^{\prime \prime} \mathrm{S} 039^{\circ} 5^{\prime} 21.00^{\prime \prime} \mathrm{W}\right)$. There is a community that lives in precarious conditions of sanitation and infrastructure between these two sampling sites. Therefore, part of the domestic sewage produced by this community is directly released into the Capivari River or kept in pits, which in turn can contaminate groundwater (Figure 2A,B).

The Paraguaçu River is one of the most important river systems in the state of Bahia, with approximately $600 \mathrm{~km}$ in length (Ingá, 2008). According to CRA (2011), one of the main uses of waters of the Paraguaçu River basin, in addition to supplying cities and industries, is for recreation and fishing (mainly in the estuarine zone). In its course, this river crosses several urbanized and agricultural areas and receives domestic and industrial sewage and pesticide residues. Sampling sites on the Paraguaçu River were: PG1 - at the Pedra do Cavalo Reservoir, municipality of Cabaceiras do Paraguaçu (12³0'49.6”S $039^{\circ} 11^{\prime} 14.1$ ' W), where there is a ferryboat crossing, a small boat dock and the frequent use of jet skis for recreation; and PG2 - downstream of the Pedra do Cavalo Dam, municipality of Cachoeira (12 $\left.2^{\circ} 36^{\prime} 11.1^{\prime \prime} \mathrm{S} 038^{\circ} 58^{\prime} 1.9^{\prime \prime} \mathrm{W}\right)$, where there is a marked degree of urbanization and constant release of untreated domestic sewage (Figure 2C,D).

The spring of the Subae River is in the municipality of Feira de Santana, extends for $55 \mathrm{~km}$ and its mouth is in the "Todos os Santos" Bay. This river has serious environmental impacts caused by the discharge of domestic and industrial effluents from agricultural and extractive activities. The sampling sites of the Subaé River were: SB1 - located on the urban limits of the municipality of Santo Amaro $\left(12^{\circ} 32^{\prime} 17.10^{\prime \prime S} 038^{\circ} 43^{\prime} 38.92^{\prime \prime W}\right)$, near the deactivated lead factory Plumbum Mineração \& Metalurgia Ltda; and SB2 - located downstream the downtown area of the municipality of Santo Amaro, where 
untreated domestic and industrial effluents are released in the river water (Figure $2 \mathrm{E}, \mathrm{F}$ ).

Figure 2. Photos from the water sampling sites at Capivari River (A,B), Paraguaçu River (C,D), and Subaé River (E,F).
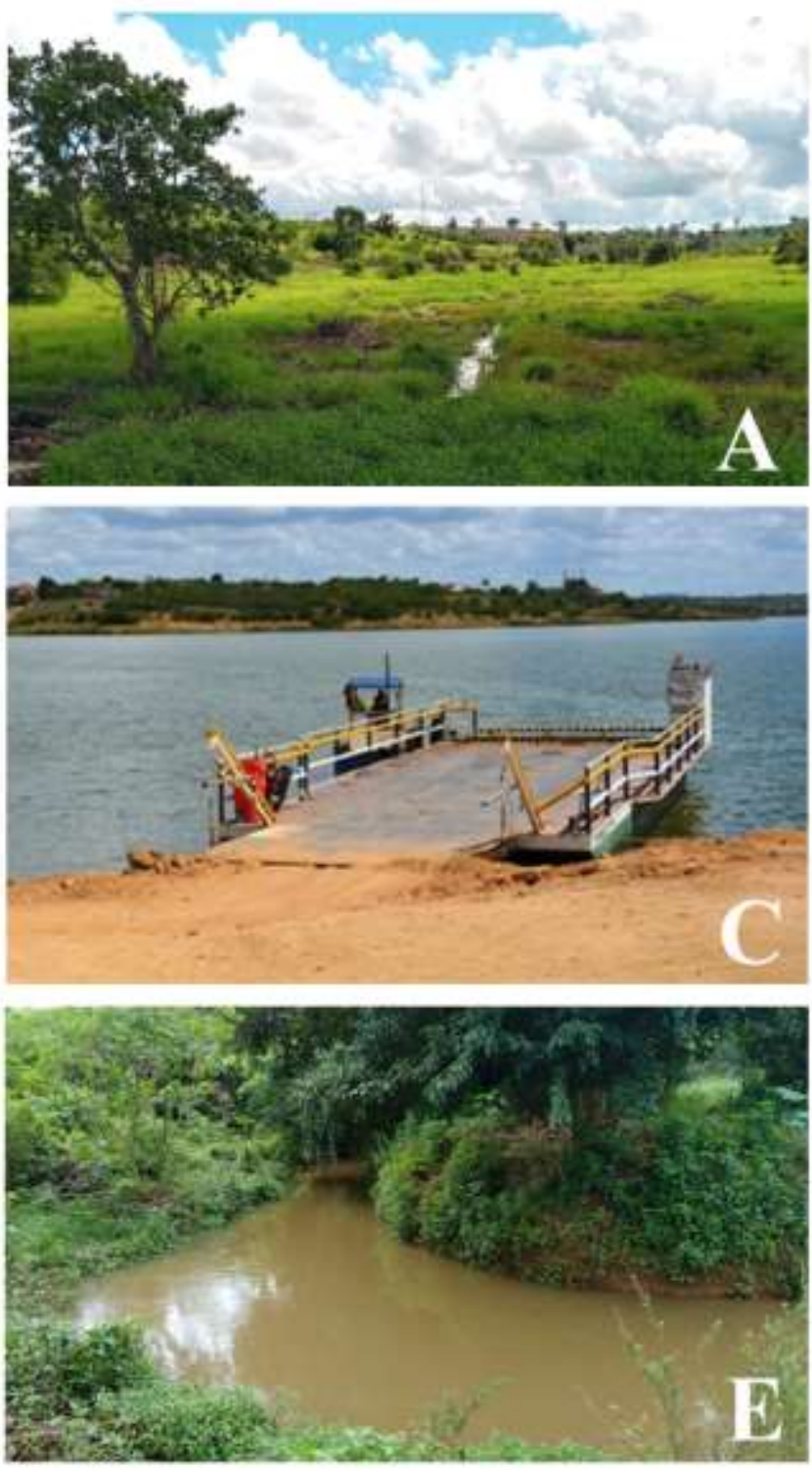
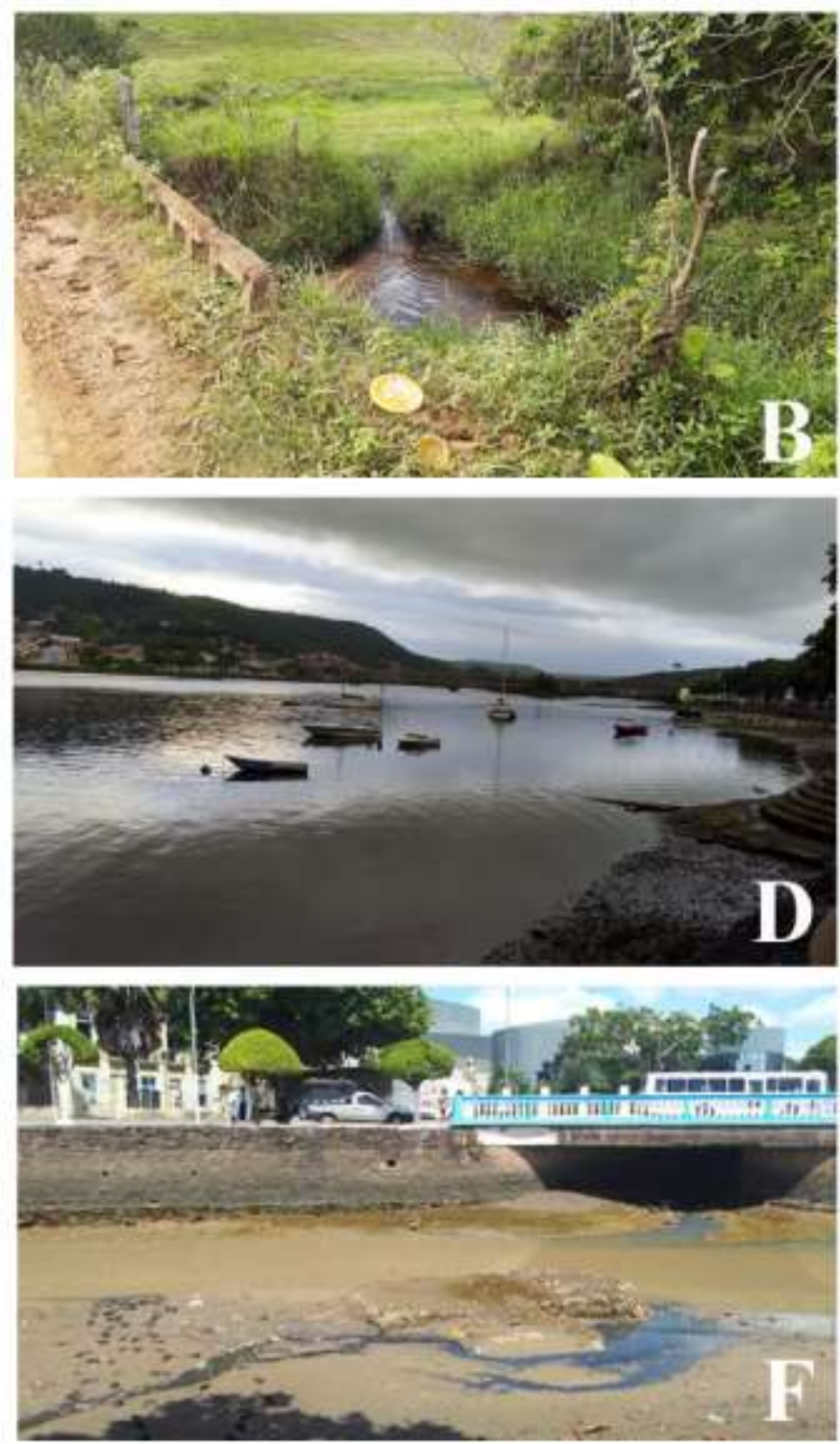

Source: Authors.

Water collections were carried out in two seasonal periods: dry season (February / 2017) and rainy season (June / 2017). Each season was defined from rainfall data (calculated from a set of data of 30 years of observation) obtained from the "Clima Tempo" website (https://www.climatempo.com.br). Precipitation values below (dry) and above (rainy) $100 \mathrm{~mm}$ were considered. From each sampling site, $50 \mathrm{~L}$ of surface water were collected with the aid of previously decontaminated polystyrene gallons. Water samples were transported to the laboratory and transferred to glass containers $(30 \mathrm{~L})$ with aeration from air blowers. Each collection point was analyzed in duplicate, concomitantly.

\subsection{Acute Exposure Test}

After $24 \mathrm{~h}$ of filling containers with water samples, $32 \mathrm{M}$. jelskii specimens were transferred to each container. As a standardization criterion, only adult prawns were used in experiments, with cephalothorax length above $6.7 \mathrm{~mm}$ (Rocha \& 
Barbosa, 2017). In the control group (CTR), prawns were exposed to previously dechlorinated laboratory water. In total, 540 M. jelskii specimens were used in experiments, with 253 animals in the dry season and 286 in the rainy season.

The test was of static type, with controlled photoperiod (12 Light / 12 Dark) and duration of $96 \mathrm{~h}$. Animals were not fed during experiments, while physicochemical parameters of water were daily monitored with a multiparameter meter (Hanna HI 9828). Mortality rate was assessed throughout the exposure period, with dead individuals counted and discarded.

\subsection{Biochemical Biomarkers}

After $96 \mathrm{~h}$ of exposure to water samples, prawns were individually removed from containers and analgesized in water containing ice (1:1) for one minute. Specimens were sexed according to presence (male) or absence (female) of the appendix masculina on the second pair of pleopods. Total body length ( $\mathrm{TL}=$ from the tip of the rostrum to the end of the telson) and carapace length ( $\mathrm{CL}$ - from the post-orbital margin to the posterior limit of the carapace) were measured to the nearest 0.01 $\mathrm{mm}$ with digital caliper. Finally, to obtain wet weight (W), precision scale (range: $0.01 \mathrm{~g}$ ) was used.

The hepatopancreas of the animals were removed with the aid of surgical material, weighed and homogenized in a proportion of 1:10 (m/v) in potassium phosphate buffer (Tris- $\mathrm{HCl}, 50 \mathrm{mM}, 0,15 \mathrm{M} \mathrm{KCl}, \mathrm{pH} 6,8$ ). Due to the small size and weight of the hepatopancreas of M. jelskii, it was necessary to compose the sample from a pool. Thus, the hepatopancreatic tissue of three adult individuals was combined in order to compose each sample pool, with volume of at least $0.04 \mathrm{~g}$ required for analysis.

The homogenized hepatopancreatic tissue was centrifuged for 25 minutes $\left(4^{\circ} \mathrm{C}\right)$ at $12.300 \mathrm{~g}$. After this procedure, the supernatant was separated and frozen at $-80{ }^{\circ} \mathrm{C}$ for later determination of the activity of CAT and GST enzymes. CAT activity ( $\mu \mathrm{mol} \mathrm{H}_{2} \mathrm{O}_{2}$ min $^{-1} \mathrm{mg} \cdot \mathrm{pt}^{-1}$ ) was determined based on the degradation of exogenous $\mathrm{H}_{2} \mathrm{O}_{2}$ by CAT, generating $\mathrm{H}_{2} \mathrm{O}$ and $\mathrm{O}_{2}$ as by-products (Aebi, 1984). The readings were performed on the UV/Vis spectrophotometer (Reaction kinetics software) in

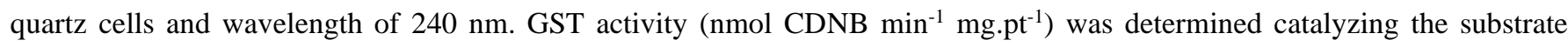
conjugation reaction 1-26 chlorine-2,4-dinitrobenzene (CDNB) with reduced glutathione, in acrylic cells and wavelength of $340 \mathrm{~nm}$ (Keen, Habig \& Jakoby, 1976). The total protein concentration in the hepatopancreas was quantified using commercial kit (Interkit®).

\subsection{Statistical analysis}

In our work, we used the experimental method of a quantitative nature (Pereira et al., 2018), with the analysis of the mean and standard deviation values of the analyzed biomarkers. Discriminant Analysis in a descriptive context (Williams, 1984) was used to evidence the most similar sampling points according to responses of biochemical biomarkers of prawns. For that, four variables were used to group sampling points: CAT activity in the dry and rainy season and GST activity in the dry and rainy season.

To identify significant differences in the responses of biomarkers (CAT and GST) among sampling points, three-way ANOVA was used (Sokal \& Rohlf, 1995). Two three-factor ANOVA were performed, one using the CAT enzyme activity as response variable and the other using the GST enzyme activity as response variable. The three categorical variables were: i) three different rivers (Capivari, Paraguaçu and Subaé); ii) two different seasons (dry and rainy); and iii) three types of points (control points, points upstream the river (point 1) and points downstream the river (point 2). Differences among rivers, season, and points were considered significant at probability value $<0.05$. 


\section{Results}

Discriminant analysis showed that the CAT and GST activity in prawns exposed to water samples collected in both sites of the Capivari River were very similar, composing a single group of data (Figure 3). On the other hand, data sets of the enzymatic activity of prawns exposed to water from the Paraguaçu and Subaé rivers composed distinct groups of data for each sampling site (Figure 3). In this context, a slight difference in the enzymatic activity of animals exposed to water from both sites at Paraguaçu River was observed. Conversely, it was observed that the results of biomarkers evaluated in prawns exposed to water from SB1 were quite different, when compared to result of exposure to SB2 and even to the other points sampled in the other two rivers (Figure 3).

Figure 3. Enzymatic activity variation across all sample points of Capivari (CP), Paraguaçu (PG), and Subaé rivers (SB), using the two main discriminant factors of the Discriminant Analysis.

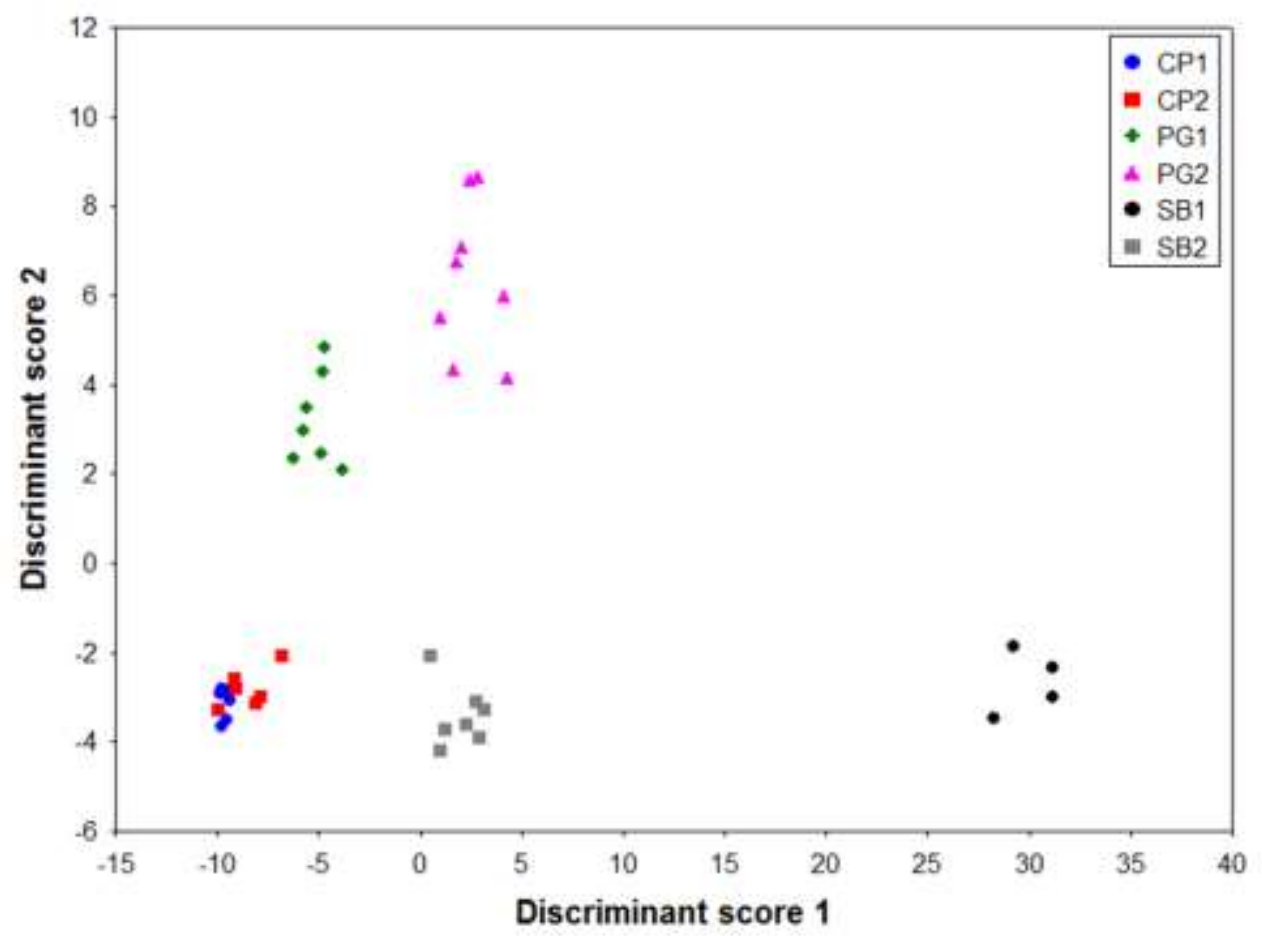

Source: Authors.

Catalase activity in prawns was significantly different among points, seasons, and rivers $(\mathrm{F}=61.19, \mathrm{p}=0$; specific differences can be viewed comparing interval confidences in Figure 4). In the Capivari River, results showed significant

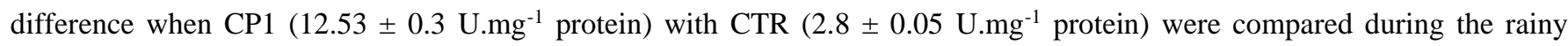
season. Furthermore, in CP1, the CAT activity was significantly higher in the rainy season, when compared with the dry season $\left(4.54 \pm 0.1 \mathrm{U} \cdot \mathrm{mg}^{-1}\right.$ protein). On the other hand, in CP2, the CAT activity did not vary between dry and rainy seasons.

In the Paraguaçu River, the CAT activity was significantly higher in PG2, when compared to CTR and PG1. This result was observed in both seasons. In the Paraguaçu River, the highest values of CAT activity were observed in animals exposed to water from PG2, in the dry season $\left(33.78 \pm 0.4 \mathrm{U}_{\mathrm{mg}} \mathrm{mg}^{-1}\right.$ protein $)$ and in the rainy season $\left(45.41 \pm 1.4 \mathrm{U}_{\mathrm{mg}} \mathrm{m}^{-1}\right.$ protein), when compared to CTR and PG1. Comparing seasonality, it was observed that the CAT activity was higher in PG2, in the rainy season. 
Finally, in the Subaé River, the CAT activity of SB1 and SB2 was significantly higher than that of CTR, both in the dry and rainy seasons. Comparing both sampling sites, the activity of this enzyme was significantly higher in SB1 in both

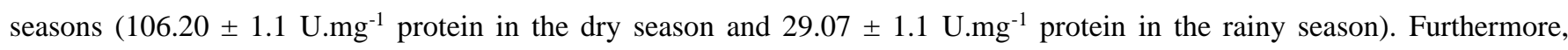
higher CAT activity was observed in animals exposed to water samples from SB1 and SB2 collected during the dry season.

Figure 4. Mean catalase activity values in the hepatopancreas of Macrobrachium jelskii exposed for 96h to water samples from Capivari, Paraguaçu and Subaé rivers in the dry and rainy seasons. Bars represent confidence intervals at 0.95 level.
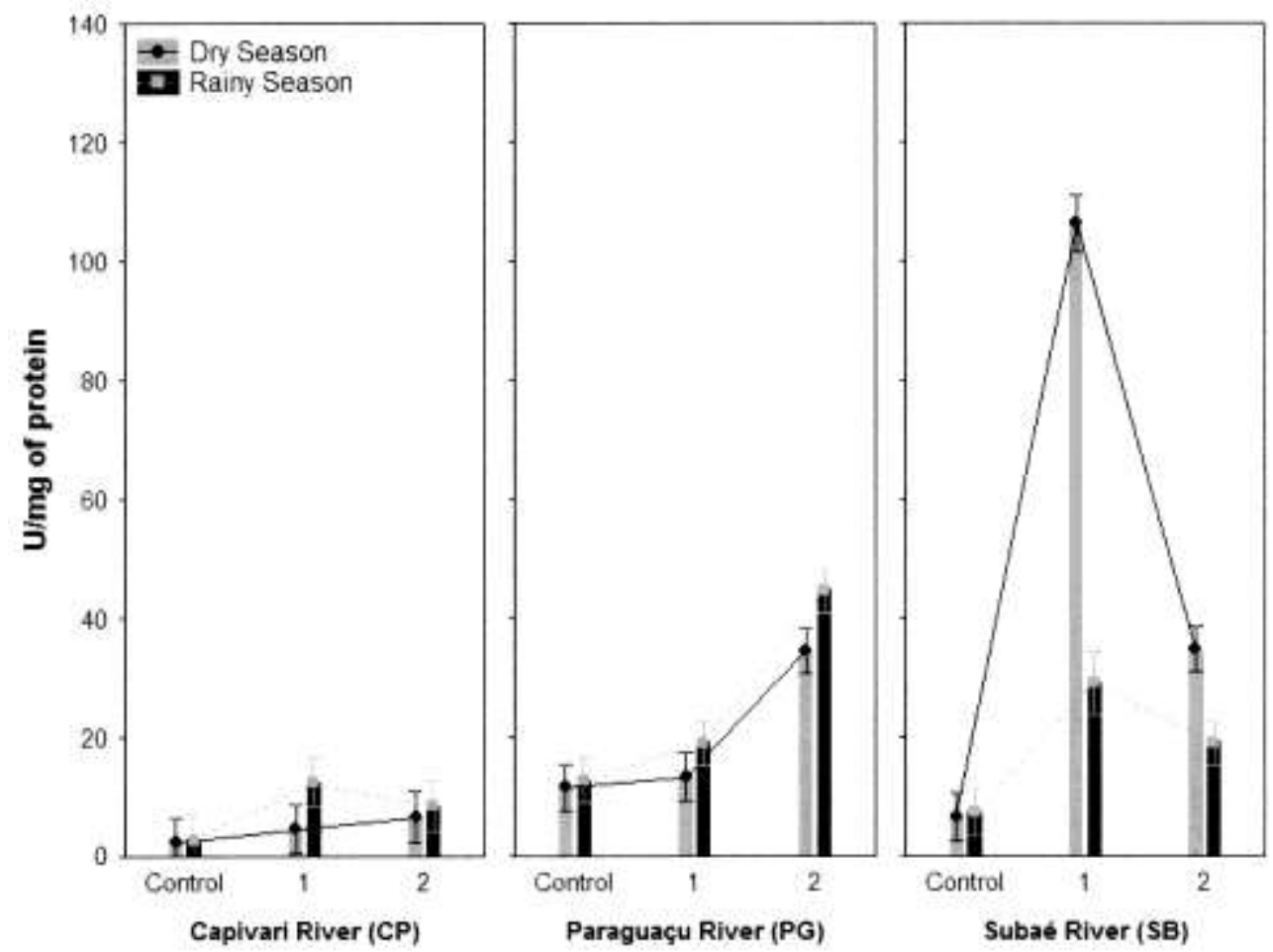

Source: Authors.

In benthic macroinvertebrates, the catalase activity differs broadly from taxa to taxa, ranging from 3.0 to $100.0 \mathrm{U}$ (Berra et al., 2004). However, as far as we know, specific data about this enzyme in M. jelskii are not available in the literature. The present study showed that the catalase activity in $M$. jelskii ranged from 2.4 to $106.2 \mathrm{U}$, which is similar to that reported by Berra et al. (2004).

The GST activity in prawns was significantly different among points, seasons, and rivers $(\mathrm{F}=28.90, \mathrm{p}=0$; specific differences can be viewed comparing interval confidences in Figure 5). In the Capivari River, CP1 had significantly higher activity when compared with CTR and CP2. However, in the rainy season, the highest GST activity was recorded in animals exposed to water from CP2 (194.2 $\pm 0.1 \mu \mathrm{mol} . \mathrm{min}^{-1} \mathrm{mg}^{-1}$ protein). Comparing dry and rainy seasons at the same sampling site, it was observed that the GST activity was significantly higher in CP2, in the rainy season (Figure 5). In experiments with water samples from the Paraguaçu River, the GST activity was significantly higher in prawns exposed to water from both sampling sites, when compared to CTR, in both seasons. In the dry season, the highest GST activity was observed in PG2 (676.7 \pm 0.1 $\mu$ mol. $\mathrm{min}^{-1} \mathrm{mg}^{-1}$ protein), while in the rainy season, the highest GST activity was observed in specimens exposed to water from PG1 $\left(849.3 \pm 24.1 \mu\right.$ mol. $\mathrm{min}^{-1} \mathrm{mg}^{-1}$ protein $)$.

Comparing the dry and rainy seasons, the GST activity was higher in PG1 and PG2 during the rainy season; the same pattern was observed for animals in the CTR group (Figure 5). In the Subaé River, the GST activity was significantly higher in 
SB1 and SB2 when compared to CTR, in both seasons. In addition, the activity of this enzyme was significantly higher in animals exposed to water from SB1, in both seasons (dry season: $314.4 \pm 23.6 \mu$ mol. $\mathrm{min}^{-1} \mathrm{mg}^{-1}$ protein and rainy season: 613.2 $\pm 73.6 \mu \mathrm{mol} . \mathrm{min}^{-1} \mathrm{mg}^{-1}$ protein). Considering seasonality, higher enzymatic activity was observed during the rainy season in both sampling sites (Figure 5).

Figure 5. Mean glutathione S-transferase activity values in the hepatopancreas of Macrobrachium jelskii exposed for $96 \mathrm{~h}$ to water samples from Capivari, Paraguaçu and Subaé rivers in the dry and rainy seasons. Bars represent confidence intervals at 0.95 level.
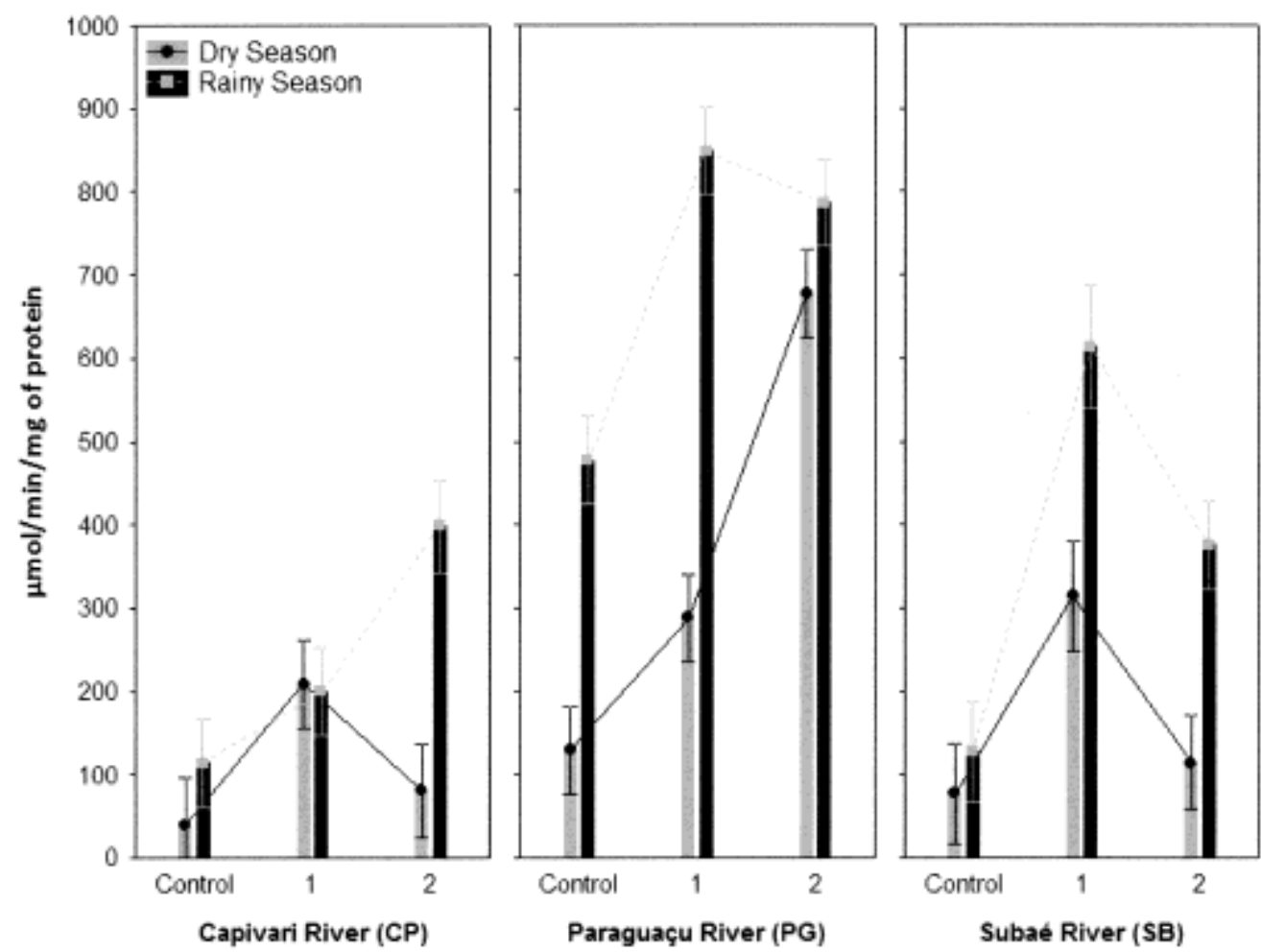

Source: Authors.

\section{Discussion}

Biomarkers are defined as alterations at cellular, physiological or biochemical level in response to a stress condition. In this context, biomarkers of oxidative stress detect alterations resulting from increased exposure to oxidant agents or reduction in antioxidant defenses (Biazus et al., 2015). In benthic macroinvertebrates the analysis of oxidative stress parameters is less widespread, but there are studies with promising results in this field (see Berra et al., 2004; Prat et al., 2013; Biazus 2015 for review).

The antioxidant defense system activates repair mechanisms, which include enzymes that regulate the reactive intermediates produced in the cells (Paital, 2018). The superoxide dismutase enzyme catalyzes the dismutation of the superoxide radical $\left(\mathrm{O}_{2}^{-}\right)$into $\mathrm{O}_{2}$ and $\mathrm{H}_{2} \mathrm{O}_{2}$ whereas, the catalase (CAT) catalyzes the conversion of $\mathrm{H}_{2} \mathrm{O}_{2}$ (toxic to cells) into $\mathrm{H}_{2} \mathrm{O}$ and $\mathrm{O}_{2}$ (Benavides et al., 2016). Thus, variations in the activity of CAT may be related to the presence of stressing substances in the water. Similarly, the GST enzyme is also important in the defense against oxidative stress, since it protects proteins, lipids and DNA from oxidation (Benavides et al., 2016). According to Zanette et al. (2011) and Turja et al. (2020), 
GST is a phase-II enzyme that conjugates electrophilic compounds with reduced glutathione (GSH), acting in the detoxification of organic contaminants (e.g., PAHs).

In our study, the highest values of CAT and GST activity were observed in animals exposed to water from sampling points with the greatest anthropic influence, mainly by domestic sewage (CP2, PG2, SB1 and SB2). Domestic sewage in Brazilian urban areas presents high concentration of pharmaceutical products, personal hygiene and surfactants, which can act as endocrine disruptor chemicals, which can cause increase in the CAT and GST activity in mussels (Zanette et al., 2008; Canesi et al., 2010; Bolong et al., 2009; Saénz et al., 2010). Thus, it could be inferred that the activity of CAT and GST enzymes of $M$. jelskii individuals exposed to water from CP2, PG2, SB1 and SB2 was influenced by the presence of xenobiotics from domestic sewage contamination. Another fact that supports this hypothesis is that the activity of both enzymes was also higher than the control group in animals exposed to water from these sampling points.

Pesticides can also cause oxidative stress in aquatic organisms (Lushchak, 2011; Vieira et al., 2014), including other prawn species. For instance, exposure to sublethal "fenitrothion" concentrations (insecticide used to control agricultural pests) increased the activity of CAT and GST enzymes in Macrobrachium borellii (Nobili, 1896) and Palaemonetes argentinus (Nobili, 1901) (Lavarías et al., 2013; Lavarías \& Garcia, 2015). These results suggest that these enzymes would be strongly involved in the detoxification of fenitrothion products during their metabolization (Lavarías et al., 2013). Gaume et al. (2014) showed that the organochlorine pesticide Chlordecone induced expression of enzymes involved in biotransformation and detoxification processes (e.g., cytochrome, P450 and GST) in Macrobrachium rosenbergii (De Man, 1879). Finally, Lafontaine et al. (2017) demonstrated the accumulation of the same pesticide in the hepatopancreas of M. rosenbergii and the action of detoxifying enzymes in this organ. In this context, it is important to note that the three rivers under study show intense agricultural activity along their courses (authors personal observation), which can cause contamination by pesticides (even if this is not the main source of water contamination), and it may have also interfered in the response of CAT and GST enzymes.

It has already been determined that antioxidant enzymes can also be good biomarkers of exposure to metals (Van der Oost, 2003; Luchchak, 2011). According to Varol \& Sen (2011) one of the main anthropogenic sources of heavy metal contamination are mining and smelting activities, in which sediments of sites downstream a copper mine plant in Turkey showed significant $\mathrm{Cd}, \mathrm{Co}, \mathrm{Cu}, \mathrm{Pb}$ and $\mathrm{Zn}$ concentrations, indicating metallic discharges. In addition, metals such as $\mathrm{Cu}, \mathrm{Pb}$ and $\mathrm{Zn}$ are components of household waste and more than $50 \%$ of these metals may come from urban sewage (Souza et al., 2016).

In our study, CAT and GST showed high activity in experiments using water from SB1. Given the history of contamination of this site (da Silva et al., 2017; Silva Júnior, 2020), the activity of such enzymes could also be related to exposure to heavy metals. In the Subaé River, in addition to inactivated lead smelter, paper and food industries, several sources of untreated sewage discharge can contribute to metal contamination (Hatje \& Barros, 2012). Hatje et al. (2009) concluded that the Subaé River, particularly in its low course (where the city of Santo Amaro is located), has high level of contamination, based on the concentration of trace metals $(\mathrm{Co}, \mathrm{Cu}, \mathrm{Pb}, \mathrm{Zn})$. In addition, the Subaé River bottom sediment is also highly rich in $\mathrm{Cd}, \mathrm{Pb}$ and $\mathrm{Zn}$ (Hatje et al., 2006; Hatje et al., 2009). Thus, we can infer that the defense system mediated by both enzymes in M. jelskii responded positively to reduce the damage caused by ROS.

Metals, such as $\mathrm{Cd}, \mathrm{Ni}, \mathrm{Cr}, \mathrm{Pb}$ and $\mathrm{Hg}$ are toxic in aquatic organisms mainly due to their oxidative potential bioaccumulation and slow biodegradation (Vlahogianni et al., 2007; Duarte et al., 2017; Carvalho Neta, 2019). Previous studies have shown that both enzymes used in our study usually respond significantly to heavy metal contamination in a variety of animals, including crustaceans. In the Saronikos Gulf (Greece), the activity of CAT enzyme in the mussel Mytilus galloprovincialis Lamarck, 1819 increased 2-3 times in a site contaminated with heavy metals compared to control site 
(Vlahogianni et al., 2007). In his review, Lushchak (2011) mentioned several studies in which the antioxidant enzymes (e.g., CAT and GST) of various fish species responded to contamination by metals (e.g., Cu, Hg). Harayashiki et al., (2018) measured the CAT and GST activities in Penaeus monidon Fabricius, 1798 juveniles fed on food contaminated with mercuric chloride and observed that it caused oxidative stress. Similarly, Capparelli et al. (2020) observed that the GST activity was higher in the hepatopancreas of the fiddler crab Uca rapax (Smith, 1870) (now Minuca rapax) exposed to copper when compared to control group. In our study, we also observed higher activity of GST in animals exposed to water from the SB1. However, in our case, CAT seems to be a biomarker more sensitive to the presence of metals, since the highest peak of activity of this enzyme was precisely in animals exposed to water from SB1.

On the other hand, GST activity was also high in animals exposed to water from PG1. In this sampling site, we observed the presence of a ferry boat and other vehicles powered by diesel oil. Crude oil and its by-products, which could be the main source of contamination at PG1, may affect aquatic organisms in many ways and oxidative stress is one of the key elements of their toxicity (Lushchak, 2011). The main pollutants from petrochemical activities include polycyclic aromatic hydrocarbons (PAHs), alkylphenols, diesel fuel, and hydrocarbons (Martínez-Gómez et al., 2006; Nudi et al., 2010; Lushchak, 2011; Zanette et al., 2011; Turja et al., 2020). For instance, PAHs are a group of organic pollutants of great impact to environment and human health (Celino et al., 2010; Sedeño-Díaz \& López-López, 2013; Turja et al., 2020). In freshwater environment, contamination by PAHs is particularly serious because the solubility of these chemicals increases in low salinities (Ramachandran et al., 2006). Furthermore, many authors have already demonstrated that environmental pollution by oil and its by-products changes the patterns of GST activity (among other enzymes) in vertebrates and invertebrates (Tim-Tim, 2009; Zanette et al., 2011; Wu et al., 2011; Moreira \& Guilhermino, 2005).

Considering the seasonal factor, there are two possibilities for increased concentration of contaminants in aquatic environments. First, during periods of greater precipitation, there is greater supply of potentially toxic substances due to leaching processes and the carrying of contaminants (Hatje \& Barros, 2012; Souza et al., 2016). Second, during dry periods, there is greater water evaporation and less flow, with consequent increase in the concentration of contaminants in water, especially of heavy metals (Obasohan \& Eguavoen, 2008; Ahmad et al., 2010; Mohiuddin et al., 2012; Shanbehzadeh et al., 2014; Mohammad Ali et al., 2016). Our results demonstrated that both possibilities seem to occur in the three rivers, since increase in the CAT and/or GST activity was observed in both seasons. However, at the rainy season, the GST activity was significantly higher at all sampling sites on the Paraguaçu (PG1 and PG2) and Subaé (SB1 and SB2) rivers. Thus, the greater GST activity in $M$. jelskii exposed to water collected from the rainy season may be related to the greater supply of potentially toxic substances as a result of leaching processes and the carrying of contaminants (Hatje \& Barros, 2012). Finally, it is noteworthy that the rainy season can also promote dilution of xenobiotics (Mohiuddin et al., 2012), which induces less oxidative stress (i.e., less enzymatic activity) during this season, as reported by Sedeño-Díaz \& López-López (2013) for the fish Chirostoma jordani Woolman, 1894 from Yurira Lake, Mexico. However, this does not seem to be the case in the present study, since, during the rainy season, we observed an increase in the activity of at least one of the analyzed enzymes in each sampling site.

Specifically in the case of the Capivari River, less prominent enzymatic responses were observed. Possibly, it occurs because this river is of lesser magnitude and/or because it crosses less urbanized areas, with predominance of agricultural or pastures activities (authors personal observation; Figure 2). Thus, it is possible that the rainfall regime had less influence on the activity of biochemical biomarkers of $M$. jelskii exposed to water from this river.

The results of the discriminant analysis revealed a strong relationship between CP1 and CP2, which indicates similar characteristics, regarding the presence of chemical substances (e.g., xenobiotics) in the water from the Capivari River. In fact, field observations (during water collection) found the presence of agricultural and pasture activities, waste and evidence of 
contamination by domestic sewage in both points. PG1 and PG2 showed different enzymatic responses, which can be explained by field observations, where these two points have different contaminant sources. Consequently, PG1 was probably contaminated by oil products, while PG2 had signs of untreated domestic effluent discharge, and these different contaminants resulted in greater distance between PG1 and PG2. A similar situation occurred in SB1 and SB2. The isolation of the points that represent the enzymatic activity in animals exposed to water from SB1 proves the existence of a different type of contamination at this site (Figure 3).

\section{Final Considerations}

The present study demonstrated that the activity of CAT and GST enzymes can be used as biomarkers in M. jelskii and this species can be used as a bioindicator in ecotoxicological tests to determine water quality. Our results also contributed to the knowledge of aspects regarding the antioxidant defense system of this species. Furthermore, this study was the first ecotoxicological evaluation using freshwater prawn biomarkers to characterize urban and rural rivers in relation to aquatic contamination in the state of Bahia. However, further studies should be carried out, including the evaluation of other biochemical exposure biomarkers in conjunction with the determination of toxic substances present in water.

In general, the enzymatic activity was significantly higher in animals exposed to water samples collected from the three rivers. Such enzymatic activities were higher in animals of experiments carried out in the rainy season, in comparison to those from the dry season. These responses may be an indicative of activation of the antioxidant defense mechanism of $M$. jelskii. Further studies, using a greater number of biochemical biomarkers, are necessary to correlate the response of biochemical biomarkers with the probable source of contamination of the studied rivers.

\section{Acknowledgments}

The authors express their sincere gratitude to Centro de Ciências Agrárias, Ambientais e Biológicas - Universidade Federal do Recôncavo da Bahia (CCAAB-UFRB) for providing all laboratory facilities, to Pró-Reitoria de Pesquisa, PósGraduação, Criação e Inovação (PPGCI-UFRB), through the National Council of Scientific and Technological Research (CNPq) for providing a research grant (PIBIC 2016/2017; Process \# 136707/2016-5) to one of the authors (TAM), and to Theila Santana, Marilene Santos and Lucas Sales for their help during laboratory activities.

\section{References}

Adams, S. M. \& Greeley, M. S. (2000). Ecotoxicological indicators of water quality: using multi-response indicators to assess the health of aquatic ecosystems. Water, Air, and Soil Pollution, 123: 103-115.

Afiyanti, M., \& Chen, H. J. (2014). Catalase activity is modulated by calcium and calmodulin in detached mature leaves of sweet potato. Journal of Plant Physiology, 171(2): 35-47. http://dx.doi.org/10.1016/j.jplph.2013.10.003

Ahmad, M. K., Islam, S.; Rahman, S.; Haque, M. R. \& Islam, M. M. (2010). Heavy Metals in Water, Sediment and Some Fishes of Buriganga River, Bangladesh. International Journal of Environmental Research, 4(2): 321-332.

Al-Fanharawia, A. A., Rabeeb, A. M. \& Al-Mamooric, A. M. J. (2018). Biochemical and molecular alterations in freshwater mollusks as biomarkers for petroleum product, domestic heating oil. Ecotoxicology and Environmental Safety, 158: 69-77. https://doi.org/10.1016/j.ecoenv.2018.04.006

Anger, K. (2013). Neotropical Macrobrachium (caridea: palaemonidae): on the biology, origin, and radiation of freshwater-invading shrimp. Journal of Crustacean Biology, 33(2): 151-183. 10.1163/1937240X-00002124

APHA. (1998). Standard Methods for the Examination of Water and Wastewater. 20th Edition, American Public Health Association, American Water Works Association and Water Environmental Federation, Washington DC, 1496p.

Araujo, C. V. M. \& Blasco, J. (2019). Spatial Avoidance as a Response to Contamination by Aquatic Organisms in Nonforced, Multicompartmented Exposure Systems: A Complementary Approach to the Behavioral Response. Environmental Toxicology and Chemistry, 38(2): 312-320. 10.1002/etc.4310

Bauer, R. T. (2004). Remarkable shrimps: Adaptations and natural history of the carideans. Norman, University of Oklahoma Press, 282p. 
Berra, E., Forcella, M., Giacchini1, R., Marziali, L., Rossaro, B. \& Parenti, P. (2004). Evaluation of enzyme biomarkers in freshwater invertebrates from Taro and Ticino river, Italy. Annales de Limnologie - International Journal of Limnology, 40 (3), 169-180. http://dx.doi.org/10.1051/limn/2004015

Bianchini A. \& Monserrat, J. M. (2007). Effects of methyl parathion on Chasmagnathus granulatus hepatopancreas: Protective role of Sesamol. Ecotoxicology and Environmental Safety, 67: 100-108. 10.1016/j.ecoenv.2006.03.006

Bolong, N., Ismail, A. F., Salim, M. R. \& Matsuura, T. (2009). A review of the effects of emerging contaminants in wastewater and options for their removal. Desalination, 239: 229-246. doi:10.1016/j.desal.2008.03.020

Canesi, L., Fabbri, R., Vallotto, D., Gallo, G., Marcomini, A. \& Pojana, G. (2010). Biomarkers in Mytilus galloprovincialis exposed to suspensions of selected nanoparticles (Nano carbon black, C60 fullerene, Nano- $\mathrm{TiO}_{2}, \mathrm{Nano}_{-} \mathrm{SiO}_{2}$ ). Aquatic Toxicology, 100: 168-177. doi:10.1016/j.aquatox.2010.04.009

Capparelli, M. V., McNamara, J. C. M. \& Grosell, M. G. (2020). Tissue accumulation and the efects of long-term dietary copper contamination on osmoregulation in the mudfat fiddler crab Minuca rapax (Crustacea, Ocypodidae). Bulletin of Environmental Contamination and Toxicology, 104:755-762. https://doi.org/10.1007/s00128-020-02872-3

Carvalho Neta, R. N. F., Andrade, T. S. O. M., Oliveira, S. R. S., Torres Junior, A. R., Cardoso, W. S., Santos, D. M. S., Batista, W. S., Serra, I. M. R. S. \& Brito, N. M. (2019). Biochemical and morphological responses in Ucides cordatus (Crustacea, Decapoda) as indicators of contamination status in mangroves and port areas from northern Brazil. Environmental Science and Pollution Research, 26: 15884-15893. https://doi.org/10.1007/s11356-019-04849-0

Celino, J. J., Corseuil, H. X., Fernandes, M. \& Garcia, K. S. (2010). Distribution and sources of polycyclic aromatic hydrocarbons in the aquatic environment: a multivariate analysis. REM - International Engineering Journal, 63(2): 211-218.

Centro de Recursos Ambientais - CRA. Bacia Hidrográfica do Rio Paraguaçu. Salvador, 2011. Avaliação da Qualidade de Água. http://www.seia.ba.gov.br.

Cirilo, A. T. O., Santos, M. C. \& Nunes, M. L. (2011). Caracterização física e nutricional do camarão "Saburica" (Macrobrachium jelskii, Miers 1877) e de produtos derivados. Scientia plena, 7(7): 1-6.

Clima Tempo (http://www.climatempo.com.br Climatempo. Previsão do tempo e Climatologia. https://www.climatempo.com.br/climatologia.

Costa, C. R., Olivi, P., Bota, C. M. R. and Espindola, E. L. G. 2008. A toxicidade em ambientes aquáticos: discussão e métodos de avaliação. Química Nova, 31(7): 1820-1830.

Silva, G. S., Gloaguen, T. V., Couto, C. F. \& Motta, P. N. S. (2017). Persistence and mobility of metals in an estuarine environment 25 years after closure of a lead smelter, Bahia State, Brazil. Environmental Earth Science, 76:548. 10.1007/s12665-017-6886-0

Davanso, M. B., Buruaem, L. M., Pimentel, M. F., Costa-Lotufo, L. V. \& Abessa, D. M. S. (2013). Biomarkers in mangrove root crab Goniopsis cruentata for evaluating quality of tropical estuaries. Marine Environmental Research, 91: 80-88. http://dx.doi.org/10.1016/j.marenvres.2013.02.006

Dedeke, G. A., Owagboriayeb, F. O., Adebamboc, A. O. \& Ademolu, K. O. (2016). Earthworm metallothionein production as biomarker of heavy metal pollution in abattoir soil. Applied Soil Ecology, 104: 42-47. https://doi.org/10.1016/j.apsoil.2016.02.013

Duarte, L. F. A., Souza C. A., Pereira, C. D. S. \& Pinheiro, M. A. A. (2017). Metal toxicity assessment by sentinel species of mangroves: In situ case study integrating chemical and biomarkers analyses. Ecotoxicology and Environmental Safety, 145: 367-376. https://doi.org/10.1016/j.ecoenv.2017.07.051

Gaume, B., Dodet, N., Thomé, Jean-Pierre and Lemoine, S. 2015. Expression of biotransformation and oxidative stress genes in the giant freshwater prawn Macrobrachium rosenbergii exposed to chlordecone. Environmental Science Pollution Research, 22: 7991-8002. 10.1007/s11356-014-3134-y

Harayashiki, C. A. Y., Reichelt-Brushett, A., Butcher, P. \& Benkendorff, K. (2018). Ingestion of inorganic mercury by juvenile black tiger prawns (Penaeus monodon) alters biochemical markers. Ecotoxicology, 27: 1225-1236. https://link.springer.com/article/10.1007/s10646-018-1975-8

Hatje, A. V. \& Andrade, J. B. (2009). Baía de Todos os Santos: aspectos oceanográficos. Ed. EDUFBA, 304p.

Hatje, V. \& Barros, F. (2012). Overview of the 20th century impact of trace metal contamination in the estuaries of Todos os Santos Bay: Past, present and future scenarios. Marine Pollution Bulletin, 64: 2603-2614. https://doi.org/10.1016/j.marpolbul.2012.07.009

Hatje, V., Barros, F., Figueiredo, D. G., Santos, V. L. C. S. \& Peso-Aguiar, M. C. (2006). Trace metal contamination and benthic assemblages in Subaé estuarine system, Brazil. Marine Pollution Bulletin, 52: 969-987. doi:10.1016/j.marpolbul.2006.04.016

Hatje, V., Bícego, M. C., Carvalho, G. C. \& de Andrade, J. B. (2009). Contaminação Química. 243-299. In: V. Hatje and J.B. Andrade (eds), Baía de Todos os Santos: Aspectos Oceanográficos. Salvador, Edufba.

Instituto de Gestão das Águas e Clima - INGÁ. Relatório de Monitoramento da Qualidade das Águas - Relatório Anual, INGÁ,. www.inga.ba.gov.br.

Key, P. B., Wirth, E. F., and Fulton, M. H. (2006). A review of grass shrimp, Palaemonetes spp., as a bioindicator of anthropogenic impacts. Environmental Bioindicators, 1:115-128. 10.1080/15555270600685115

Lafontaine, A., Gismondi, E., Dodet, N., Joaquim-Justo, C., Boulang-Lecomte, C., Caupos, F., Lemoine, S., Lagadic, L., Forget-Leray, J. \& Thomé, JeanPierre. (2017). Bioaccumulation, distribution and elimination of chlordecone in the giant freshwater prawn Macrobrachium rosenbergii: Field and laboratory studies. Chemosphere, 185: 888-898. http://dx.doi.org/10.1016/j.chemosphere.2017.07.099

Lavarías, S. \& García, C. F. (2015). Acute toxicity of organophosphate fenitrothion on biomarkers in prawn Palaemonetes argentinus (Crustacea: Palaemonidae). Environmental Monitoring and Assessment, 187: 65. 10.1007/s10661-014-4224-5 https://doi.org/10.1007/s10661-014-4224-5 
Lavarías, S., García, C., Crespo, R., Pedrini, N. \& Heras, H. (2013). Study of biochemical biomarkers in freshwater prawn Macrobrachium borellii (Crustacea: Palaemonidae) exposed to organophosphate fenitrothion. Ecotoxicology and Environmental Safety, 96: 10-16. http://dx.doi.org/10.1016/j.ecoenv.2013.05.040

Leme, D. M., Grummt, T., Oliveira, D. P., Sehr, A., Renz, S., Reine, S., Ferraz, E. R. A., Marchi, M. R. R., Machado, M. C., Zocolo, G. J. \& Marin-Morales, M. A. (2012). Genocity assessment of water soluble fractions of biodiesel and its diesel blends using Salmonella assay and the in vitro MicroFlow kit (Litron) assay. Chemosphere, 86(5): 512-520. 10.1016/j.chemosphere.2011.10.017

Lima, L. R. P. A. \& Bernardez, L. A. (2011). Characterization of the lead smelter slag in Santo Amaro, Bahia, Brazil. Journal of Hazardous Materials, 189: 692-699. doi: 10.1016/j.jhazmat.2011.02.091

Liu, Y., Han, S. L, Luo, Y., Li, L. Y., Chen, L. Q., Zhang, M. L. \& Du, Z. Y. (2020). Impaired peroxisomal fat oxidation induces hepatic lipid accumulation and oxidative damage in Nile tilapia. Fish Physiology and Biochemistry, 46:1229-1242. 10.1007/s10695-020-00785-w

Livingstone, D. R. (1998). The fate of organic xenobiotics in aquatic ecosystems: quantitative and qualitative differences in biotransformation by invertebrates and fish. Comparative Biochemistry and Physiology, 120: 43-49.

Loizzi, R. F. (1971). Interpretation of crayfish hepatopancreatic function based on fine structural analysis of epithelial cell lines and muscle network. Zeitschrift fur Zellforschung und mikroskopische Anatomie, 113: 420-440.

Lushchak, V. I. (2011). Environmentally induced oxidative stress in aquatic animals. Aquatic Toxicology, 101: 13-30. 10.1016/j.aquatox.2010.10.006

Martínez-Gómez, C., Campillo, J. A., Benedicto, J., Fernández, B., Valdés, J., García, I. \& Sánchez, F. (2006). Monitoring biomarkers in fish (Lepidorhombus boscii and Callionymus lyra) from the northern Iberian shelf after the Prestige oil spill. Marine Pollution Bulletin, 53: 305-314. doi:10.1016/j.marpolbul.2006.03.010

Melo, G. A. S. (2003). Famílias Atyidae, Palaemonidae e Sergestidae. p. 289-415. In: G.A.S. Melo (ed), Manual de identificação dos Crustacea Decapoda de água doce do Brasil. Loyola.

Mohammad A. M., Lokman A. M., Islamc, Md. S. \& Rahmand, Md. Z. (2016). Preliminary assessment of heavy metals in water and sediment of Karnaphuli River, Bangladesh. Environmental Nanotechnology, Monitoring \& Management, 5: 27-35. http://dx.doi.org/10.1016/j.enm.2016.01.002

Mohiuddin, K. M., Otomo, K., Ogawa, Y. \& Shikazono, N. (2012). Seasonal and spatial distribution of trace elements in the water and sediments of the Tsurumi River in Japan. Environmental Monitoring and Assessment, 184: 265-279. 10.1007/s10661-011-1966-1

Montoya, J. V. (2003). Freshwater shrimps of the genus Macrobrachium associated with roots of Eichhornia crassipes (Water Hyacinth) in the Orinoco Delta (Venezuela). Caribbean Journal of Science, 39(1): 155-159.

Moreira, S. M. \& Guilhermino, L. (2005). The use of Mytilus galloprovincialis acetylcholinesterase and glutathione s-transferases activities as biomarkers of environmental contamination along the northwest Portuguese coast. Environmental Monitoring and Assessment, 105: 309-325. 10.1007/s10661-005-3854-Z

Nudi, A. H., Wagener, A. L. R., Francioni, E., Sette, C. B., Sartori, A. V. \& Scofield, A. L. (2010). Biomarkers of PAHs exposure in crabs Ucides cordatus: Laboratory assay and field study. Environmental Research, 110(2): 137-145. https://doi.org/10.1016/j.envres.2009.10.014

Obasohan, E. E. \& Eguavoen, O. I. (2008). Seasonal variations of bioaccumulation of heavy metals in a freshwater fish (Erpetoichthys calabaricus) from Ogba river, Benin city, Nigeria. Indian Journal Animal Research, 42(3): 171-179.

Orebiyi, E. O., Awomeso, A. J., Martins, O., Idowu, A. O., Oguntoke, O and Taiwo, A. M. 2010. Assessment of Pollution Hazards of Shallow Well Water in Abeokuta and Environs. American Journal of Environmental Sciences, 6(1): 50-56.

Paital, B. (2018). Removing small non-enzymatic molecules for biochemical assay of redox regulatory enzymes, An exemplary comments on "Antioxidant responses in gills and digestive gland of oyster Crassostrea madrasensis (Preston) under lead exposure. Ecotoxicology and Environmental Safety, 154: 337340. https://doi.org/10.1016/j.ecoenv.2018.01.051

Pereira, A. S., Shitsuka, D. M., Parreira, F. J. \& Shitsuka, R. (2018). Metodologia da Pesquisa Científica. [free e-book]. Santa Maria: RS. Ed. UAB/NTE/UFSM.

Ramachandran, S. D., Sweezey, M. J., Hodson, P. V., Boudreau, M., Courtenay, S. C., Lee, K., Thomas, K. \& Dixon, J. A. (2006). Influence of salinity and fish species on PAH uptake from dispersed crude oil. Marine Pollution Bulletin, 52: 1182-1189. doi:10.1016/j.marpolbul.2006.02.009

Ramsdorf, W. A., Vicari, T., Almeida, M. I. M., Artoni, R. F. \& Cestari, M. M. (2012). Handling of Astyanax sp. for biomonitoring in Cangüiri Farm within a fountainhead (Iraí River Environment Preservation Area) through the use of genetic biomarkers. Environmental Monitoring and Assessment, 184(10): 58415849 .

Rocha, S. S. \& Barbosa, R. J. (2017). Population biology of Macrobrachium jelskii (Miers, 1877) (Decapoda, Palaemonidae) from an artificial pond in Bahia, Brazil. Nauplius, 25(8): 1-13. 10.1590/2358-2936e2017023

Rosner, A., Armengaud, J., Ballarin, L., Barnay-Verdier, S., Cima, F., Coelho, A. V., Domart-Coulon, I., Drobne, D., Genevière, A. M., Kokalj, A. J., Kotlarska, E., Lyons, D. M., Mass,T., Paz, G., Pazdro, K., Perić, L., Ramšak, A., Rakers, S., Rinkevich, B., Spagnuolo, A., Sugni, M. \& Cambier, S. (2021). Stem cells of aquatic invertebrates as an advanced tool for assessing ecotoxicological impacts. Science of the Total Environment, 771 . https://doi.org/10.1016/j.scitotenv.2020.144565

Sáenz, L. A., Seibert, E. L., Zanette, J., Fiedler, H. D., Curtius, A. J., Ferreira, J. F., Almeida, E. A., Marques, M. R. F. \& Bainy, A. C. D. (2010). Biochemical biomarkers and metals in Perna perna mussels from mariculture zones of Santa Catarina, Brazil. Ecotoxicology and Environmental Safety, 73(5): 796-804. https://doi.org/10.1016/j.ecoenv.2010.02.015 
Schirmer, M., Reinstorf, F., Leschik, S., Musolff, A., Krieg, R., Strauch, G., Molson, J. W., Martienssen, M. \& Schirmer, K. (2011). Mass fluxes of xenobiotics below cities: challenges in urban hydrogeology. Environmental Earth Sciences, 64(3): 607-617.

Schvezov, N., Lovrich, G. A. \& Romero, M. C. (2017). Oxidatide stress during re-immersion of the king crab Lithodes santolla (Molina, 1782) (Decapoda: Anomura: Lithodidae) after air exposure. Journal of Crustacean Biology, 37(2), 195-203. 10.1093/jcbiol/rux004

Sedeño-Díaz, J. E. \& López-López, E. (2013). Freshwater fish as sentinel organisms: From the molecular to the population level, a review. Chapter 4. New Advances and Contributions to Fish Biology. http://dx.doi.org/10.5772/54825

Silva Júnior, J. B., Abreu, I., M., de Oliveira, D. A. F., Hadlicha, G. M. \& Barbosa, A. C. R. A. (2020). Combining geochemical and chemometric tools to assess the environmental impact of potentially toxic elements in surface sediment samples from an urban river. Marine Pollution Bulletin, 155: https://doi.org/10.1016/j.marpolbul.2020.111146

Sokal, R. R. \& Rohlf, J. F. (1995). Biometry: the principles and practice of statistics in biological research. 3rd ed. New York, W.H Freeman. 887p.

Souza, A. M., Salviano, A. M., Melo, J. F. B., Felix, W. P., Belém, C. S. \& Ramos, P. N. (2016). Seasonal study of concentration of heavy metals in waters from lower São Francisco River basin, Brazil. Braziliam Journal Biology, 76(4): 967-974. doi:org/10.1590/1519-6984.05215

Stien, X., Percic, P. M., Gnassia-Barelli, M., Roméo, M., Lafaurie, M. 1998. Evaluation of biomarkers in caged fishes and mussels to assess the quality of waters in a bay of the NW Mediterranean Sea. Environmental Pollution, 99(3): 339-345.

Sundar, S., Heino, J., Roque F. O., Simaika, J. P., Melo, A. S., Tonkin, J. D., Nogueira, D. G. \& Silva, D. P. (2020). Conservation of freshwater macroinvertebrate biodiversity in tropical regions. Aquatic Conservation: Marine and Freshwater Ecosystems, 30: 1238-1250. 10.1002/aqc.3326

Tim-Tim, A. L. S., Morgado, F., Moreira, S., Rangel, R., Nogueira, A. J. A., Soares, A. M. V. M. \& Guilhermino, L. (2009). Cholinesterase and glutathione Stransferase activities of three mollusc species from the NW Portuguese coast in relation to the 'Prestige' oil spill. Chemosphere, 77: 1465-1475. doi:10.1016/j.chemosphere.2009.10.014

Tumminello, R. A. \& Fuller-Espie, S. L. (2013). Heat stress induces ROS production and histone phosphorylation in celomocytes of Eisenia hortensis. International Surgery Journal, 10: 50-57.

Turja, R., Sanni, S., Stankevičiūte, M., Butrimavičienė, L., Devier, M. H., Budzinski, H. \& Lehtonen, K. K. (2020). Biomarker responses and accumulation of polycyclic aromatic hydrocarbons in Mytilus trossulus and Gammarus oceanicus during exposure to crude oil. Environmental Science and Pollution Research, 27:15498-15514. https://doi.org/10.1007/s11356-020-07946-7

Van der Oost, R., Beyer, J. \& Vermeulen, N. P. E. (2003). Fish bioaccumulation and biomarkers in environmental risk assessment: a review. Environmental Toxicology and Pharmacology, 13: 57-149.

Varol, M. \& S Sen, B. (2012). Assessment of nutrient and heavy metal contamination in surface water and sediments of the upper Tigris River, Turkey. Catena, 92: 1-10. 10.1016/j.catena.2011.11.011

Vieira, C. E. D., Almeida, M. S., Galindo, B. A., Pereira L. \& Martinez, C. B. R. (2014). Integrated biomarker response index using a Neotropical fish to assess the water quality in agricultural areas. Neotropical Ichthyology, 12(1): 153-164. 10.1590/S1679-62252014000100017

Vlahogianni, T., Dassenakis, M., Scoullos, M. J. \& Valavanidis, A. (2007). Integrated use of biomarkers (superoxide dismutase, catalase and lipid peroxidation) in mussels Mytilus galloprovincialis for assessing heavy metals' pollution in coastal areas from the Saronikos Gulf of Greece. Marine Pollution Bulletin, 54: 1361-1371. doi:10.1016/j.marpolbul.2007.05.018

Vogt, G. (2013). Abbreviation of larval development and extension of brood care as key features of the evolution of freshwater Decapoda. Biological Reviews of the Cambridge Philosophical Society, 88: 81-116. 10.1111/j.1469-185X.2012.00241.x

Weis, J. S. (2014). Physiological, developmental and behavioral effects of marine pollution. Berlin, Springer-Dordrecht. 454p. https://doi.org/10.1007/978-94007-6949-6

Williams, A. B. (1984). Shrimps, lobsters and crabs of the eastern United States, Maine to Florida. Washington, Smithsonian Institution Press, 500p.

Wu, S., Wu, E., Qiu, L., Zhong, W. \& Chen, J. (2011). Effects of phenanthrene on the mortality, growth, and anti-oxidant system of earthworms (Eisenia fetida) under laboratory conditions. Chemosphere, 83: 429-434. 10.1016/j.chemosphere.2010.12.082

Zagatto, P. A. \& Bertoletti, E. (2008). Ecotoxicologia Aquática: princípios e aplicações. Ed. Rima. 478p.

Zanette J., Almeida E. A., Silva, A. Z., Guzenski, J., Ferreira, J. F., Di Mascio, P., Marques, M. R. F. and Bainy, A. C. D. 2011. Salinity influences glutathione S-transferase activity and lipid peroxidation responses in the Crassostrea gigas oyster exposed to diesel oil. Science of the Total Environment, 409: 1976-1983. doi:10.1016/j.scitotenv.2011.01.048

Zanette, J., Nunes, F. F., Medeiros, I. D., Siebert, M. N., Mattos, J. J., Lüchmann, K. H., Melo, C. M. R. \& Bainy, A. C. D. (2008). Comparison of the antioxidant defense system in Crassostrea rhizophorae and Crassostrea gigas exposed to domestic sewage discharges. Marine Environmental Research, 66: 196-198. 10.1016/j.marenvres.2008.02.057 